\title{
AKAR GERAKAN TEOLOGI \\ POLITIK FUNDAMENTALISME ISLAM ABAD MODERN PERSPEKTIF KAREN ARMSTRONG
}

\author{
Rohmatul lzad \\ Universitas Gadjah Mada Yogyakarta, Indonesia \\ E-mail: rohmatulizad@yahoo.com
}

\begin{abstract}
The article analyzes the root of political movement of Islamic fundamentalism in the modern era with particular focus on tracing theological and political reason of this group in Karen Armstrong's work. The author tries to critically discuss Armstrong's views about political ideology held by the Islamic fundamentalism. Since the Islamic fundamentalism needs to be carefully understood as a political movement, it can help us to clearly identify their position along with their ideological basis they fight for. This study concludes that various types and forms of what so-called "fundamentalism" should be essentially observed as politicaltheological discourse; a sort of nationalism or ethnicity which is articulated in religiously manner. Therefore, fundamentalism can be understood as a political movement based on Islamic ideology. Furthermore, the theology and ideology of fundamentalists have been psychologically rooted from fear and anxiety. It has been a result of their assumption that the proponents of secularism would annihilate them. The fundamentalism is not an obsolete matter from the past; rather it is a modern and innovative movement.
\end{abstract}

Keywords: Political-theological movement, Islamic fundamentalism, secularism.

\begin{abstract}
Abstrak: Artikel ini menganalisis secara kritis akar gerakan teologi politik fundamentalisme Islam perspektif Karen Armstrong yang harus dipahami sebagai gerakan politik. Artikel ini menyimpulkan dua hal penting, yaitu: pertama, banyak bentuk dari apa yang disebut "fundamentalisme" harus dilihat secara esensial sebagai wacana teologi politik, yakni bentuk nasionalisme atau etnisitas yang diartikulasikan secara religius. Kedua, secara psikologis, teologis, dan ideologis kaum fundamentalis berakar dalam ketakutan. Hal ini berawal dari pehamanan mereka bahwa kaum sekuler akan melenyapkan mereka. Benturan antara kaum fundamentalis dengan sistem sekuler modern tidak jarang menjadi problem yang paling krusial dan menciptakan permusuhan dan konflik berkepanjangan. Akan tetapi, jika kedua belah pihak bisa saling memahami, maka gerakan fundamentalis dapat sedikit dibendung tanpa harus mempersoalkan modernitas dan segala konsekuensinya.
\end{abstract}

Kata Kunci: Teologi politik; fundamentalisme Islam; sekularisme. 


\section{Pendahuluan}

Salah satu perkembangan mengejutkan pada akhir abad kedua puluh adalah munculnya di setiap tradisi agama besar sebuah kesalehan militan yang secara populer disebut "fundamentalisme". Kebangkitan kembali jenis keagamaan ini telah mengejutkan banyak pengamat. Pada tahun-tahun pertengahan abad kedua puluh, pada umumnya diterima bahwa sekularisme merupakan kecenderungan yang tak dapat dibalikkan lagi dan bahwa agama tak akan pernah lagi memainkan peran utama dalam peristiwa-peristiwa dunia. Orang mengandaikan bahwa ketika umat manusia menjadi lebih rasional, mereka entah tidak lagi membutuhkan agama atau akan puas dengan membatasi agama di wilayah-wilayah yang sangat privat dalam kehidupan mereka. ${ }^{1}$ Tetapi, pada akhir 1970-an, kaum fundamentalis mulai memberontak melawan kekuasaan sekularisme dan mulai mencabut agama dari tempatnya di pinggiran serta menaruhnya lagi di panggung utama.

Sejauh ini, media Barat sering memberikan kesan bahwa bentuk religiositas kontroversial dan keras yang disebut sebagai "fundamentalisme" ini adalah fenomena Islam murni. Itu tidak benar. Sebagaimana diungkapkan Karen Armstrong bahwa fundamentalisme adalah kenyataan global dan telah mengemuka di setiap agama besar sebagai respons terhadap masalah-masalah modernitas. Ada fundamentalisme Yahudi, fundamentalisme Kristen, fundamentalisme Hindu, fundamentalisme Budha, dan bahkan fundamentalisme Konghucu. Fundamentalisme bukanlah gerakan monolitik; setiap bentuk fundamentalisme, bahkan di dalam tradisi yang sama, berkembang secara independen dan memiliki simbol-simbol dan antusiasme yang khas, tetapi semua penjelmaannya yang berbeda-beda memiliki kemiripan satu sama lain. ${ }^{2}$

Dalam segala bentuknya, fundamentalisme adalah iman yang sangat reduktif. Dalam kecemasan dan ketakutan mereka, kaum fundamentalis sering mendistorsi tradisi yang mereka coba bela. Fundamentalisme Islam misalnya, banyak mengabaikan pluralisme alQur'ān dan mengutip ayat-ayat al-Qur'ān yang lebih agresif untuk membenarkan kekerasan, terang-terangan mengabaikan ayat yang jauh

${ }^{1}$ Karen Armstrong, Berperang Demi Tuhan: Fundamentalisme dalam Islam, Kristen, dan Yahudi, terj. T. Hermaya (Bandung: Mizan, 2013), 15

2 Karen Armstrong, Sejarah Islam: Telaab Ringkas-Komprehensif Perkembangan Islam Sepanjang Zaman, terj. Yuliani Liputo (Bandung: Mizan, 2014), 232. 
lebih banyak yang menyerukan perdamainan, toleransi, dan sikap memaafkan. ${ }^{3}$ Kaum fundamentalisme yakin bahwa mereka berjuang atas nama Tuhan, tetapi sebenarnya religiositas jenis ini mewakili kemunduran dari Tuhan. Alih-alih merupakan iman yang tipikal, fundamentalisme merupakan penyimpangan.

Menurut Hendropriyono, ${ }^{4}$ sebagai langkah awal fundamentalisme Islam harus dilihat sebagai suatu reaksi terhadap masalah-masalah yang mengiringi modernitas, yang dianggap telah keluar terlalu jauh dari ajaran Islam. Kecenderungan ini merupakan gejala ideologis sebagai respons terhadap gejala ideologis pula yang antara lain merupakan buah dari benturan antara budaya. Oleh karena itu, fundamentalisme Islam dapat dikaitkan dengan realitas geopolitik internasional serta pemikira di balik realitas internasional tersebut. Terdapat beberapa argumen yang bisa menjelaskan mengapa sebagian kelompok fundamentalisme Islam menggunakan kekerasan sebagai jalan dalam memperjuangkan aspirasi politiknya. Pertama, pada tataran geopolitik global, umat Islam di Timur Tengah berada dalam posisi yang tidak menguntungkan, baik secara politik maupun ekonomi. Kedua, refeksi terhadap kejayaan Islam yang pernah diraih beberapa abad yang lalu serta kesimpulan subjektif yang menganggap umat Islam mundur karena meninggalkan ajaran yang telah digariskan oleh Allah dan oleh karenanya harus diperjuangkan kembali dengan menegakkan sharí'ah Allah.

Armstrong ${ }^{5}$ mengungkapkan bahwa banyak bentuk dari apa yang disebut "fudamentalisme Islam" harus dilihat secara esensial sebagai wacana politik, yakni bentuk nasionalisme atau etnisitas yang diartikulasikan secara religius. Terkadang dipahami fundamentalisme bukan sekadar sebuah cara untuk menggunakan agama untuk tujuan politik, tetapi ini pada dasarnya merupakan pemberontakan terhadap pengucilan "yang ilahi" dari kehidupan publik oleh kaum sekuler. Dengan demikian kaum fundamentalis berupaya kuat membuat nilainilai spiritual berlaku di dunia modern. Tetapi, sebagaimana telah diungkapkan, bahwa ketakutan dan keputusasaan yang menggerakkan fundamentalis juga cenderung mendistorsi tradisi keagamaan dan

\footnotetext{
3 Karen Armstrong, Masa Depan Tuban: Sanggahan terbadap Fundamentalisme dan Ateisme, terj. Yuliani Liputo (Bandung: Mizan, 2011), 470.

4 A. M. Hendropriyono, Terorisme: Fundamentalisme Kristen, Yabudi, dan Islam (Jakarta: Kompas, 2009), 164.

5 Armstrong, Berperang Demi Tuhan, 476.
} 
menonjolkan aspek-aspek yang lebih agresif dengan mengorbankan aspek-aspek toleransi dan rekonsiliasi.

Penting untuk menekankan antusiasme awal terhadap modernitas, karena terlalu banyak orang Barat menganggap Islam pada dasarnya bersifat fundamentalis, sedari dulu bertentangan dengan demokrasi dan kebebasan, dan secara kronis kecanduan modernitas. Tetapi, Islam adalah yang terakhir mengembangkan jalur fundamentalis di antara ketiga monoteisme; itu baru berkembang pada akhir 1960-an setelah bencana kekalahan orang Arab dari Israel dalam Perang Enam Hari 1967, ketika ideologi nasionalisme dan sosialisme Barat, yang tidak mendapat dukungan akar rumput, tampaknya telah gagal. Agama tampak seperti cara baru untuk kembali ke akar-akar prakolonial dari budaya mereka dan mendapatkan kembali identitas yang lebih otentik.

Fundamentalisme, bagaimanapun, sejauh ini telah berhasil mendorong agama dari pinggiran dan mengembalikannya ke panggung tengah, sehingga sekarang agama sekali lagi memainkan peranan utama dalam urusan internasional; suatu perkembangan yang akan tak terbayangkan pada pertengahan abad kedua puluh ketika sekularisme tampak sedang menanjak. Demikianlah yang terjadi di Dunia Islam sejak 1970-an. ${ }^{6}$

\section{Kemunculan Fundamentalisme dalam Islam}

Akar kemunculan dari semangat konservatisme dalam Islam dapat dilihat melalui awal mula sejarah Islam. Masyarakat Muslim konservatif pada umumnya menatap ke belakang pada sebuah zaman keemasan, zaman itu adalah periode Nabi Muhammad (570-632) dan keempat khalifah räshidūn yang menggantikan Nabi. Mereka memerintah masyarakat menurut hukum Islam. Tidak ada pemisahan antara agama dan negara. Muhammad adalah nabi sekaligus pemimpin politik masyarakat. Al-Qur'ān, sebuah kitab suci yang diwahyukan yang dibawanya bagi bangsa Arab pada tahun-tahun awal abad ketujuh, menegaskan bahwa tugas utama seorang Muslim adalah menciptakan masyarakat yang egaliter dan adil. ${ }^{7}$

Kenyataan di atas menjadi mungkin karena memang Islam adalah agama universal yang selalu cocok dengan tempat dan zaman; ia dianggap selalu kontekstual dan relevan bagi semua perkembangan zaman. Dengan demikian, masyarakat yang disebut konservatif itu

${ }^{6}$ Armstrong, Sejarah Islam, 235.

${ }^{7}$ Armstrong, Berperang Demi Tuhan, 79. 
tidak selalu bersifat statis. Sepanjang sejarah Islam misalnya, ada semacam gerakan-gerakan ișlāh (reformasi) dan tajdìd (pembaruan) yang sering sangat revolusioner. Sebagai contoh, seorang reformis seperti Ahmad b. Taymìyah misalnya, menolak ditutupnya pintu-pintu ijtihad. Gerakan-gerakan reformasi biasanya terjadi pada periode perubahan budaya atau setelah sebuah bencana politik besar. Dengan itu, Ibn Taymiyah ingin memutakhirkan sharīah agar dapat memenuhi kebutuhan nyata kaum Muslim dalam keadaan-keadaan yang berubah secara drastis ini. Tetapi sebenarnya, program-program Ibn Taymiyah bersifat koservatif. Ibn Taymīyah mengatakan bahwa untuk mengatasi krisis, kaum Muslim harus kembali ke sumbersumber agama, terutama kepada al-Qur'ān dan Sunnah Nabi. ${ }^{8}$

Di era modern, semangat konservatisme ini menemukan bentuk barunya dengan apa yang sebut sebagai "fundamentalisme". Dikatakan demikian karena secara inheren mereka terkungkung pada masa lampau, sementara gagasan-gagasan mereka bersifat modern dan sangat inovatif, sehingga fenomena ini merupakan bentuk fakta baru bagi kebangkitan Islam di era modern. Antara perspektif masa lalu dan modern, perbedaan bentuk fundamentalisme terletak pada tantangan modernitas itu sendiri, di mana kaum fundamentalis modern lebih banyak menemukan tantangan yang sepenuhnya baru dan tantangan itu bagian dari apa yang telah dilahirkan oleh zaman modern. Mereka, misalnya, menolak demokrasi dan sekularisme sebagai ciri khas masyarakat modern, dan kurang memiliki gairah untuk mengembangkan ilmu pengetahuan. Seakan-akan kaum fundamentalis tidak memiliki waktu untuk demokrasi, toleransi agama, pluralisme, menjaga kedamaian, atau memisahkan agama dan negara demi kesucian agama itu sendiri dari permasalahanpermasalahan duniawi yang terkadang amat merisaukan dan pelik.

Gerakan fundamentalisme dalam Islam dipandang memiliki beberapa kemiripan dengan gerakan serupa dalam Kristen dan Yahudi, yang tampak sebagai fenomena dengan kecenderungan yang sama. Istilah fundamentalisme Islam (al-Ușülīyah al-Islämìyah) kemudian menjadi resmi dalam wacana global, khususnya dalam kajian sosiologi agama. Ibn Taymìyah misalnya, sebagai salah satu insipirator gerakan kebangkitan ini, kadang-kadang oleh sebagian orang Barat dijuluki sebagai "Bapak fundamentalisme dalam Islam pada zaman modern".

${ }^{8}$ Ibid., 85. 
Pada umumnya, fundamentalisme dipahami sebagai sebuah kecenderungan untuk memperjuangkan sesuatu secara radikal dan dalam konteks Islam gerakan ini sering disebut sebagai gerakan perjuangan untuk menegakkan shari' ${ }^{-} a h$ Islam walaupun kadangkadang mereka berada di suatu daerah atau negara yang bukan Islam. Banyak negara yang mengalami instabilitas politik karena menerapkan sistem demokrasi juga menjadi faktor pendorong tumbuh suburnya fundamentalisme. Bagi mereka, demokrasi adalah sistem pemerintahan yang tidak stabil karena landasannya berangkat dari pergulatan empiris pemikiran manusia yang sekuler. Sebaliknya, sistem Islam menurut pendapat kelompok ini lebih menjamin stabilitas. ${ }^{9}$

Terdapat dua pendekatan untuk memahami gejala fundamentalisme, yakni objektivisme dan subjektivisme. Dari perspektif objektivis, dipahami bahwa fundamentalisme muncul karena teks agama memberikan legitimasi demikian. Perspektif subjektivis, yang menempatkan individu sebagai subjek yang aktif mendefinisikan hidupnya dengan dunia luar, maka segala fundamentalisme tidak hanya dipahami karena teks agama mengajarkan demikian. Sebagaimana telah diungkapkan di atas, dunia luar juga menjadi entitas yang juga turut mempengaruhi seseorang dalam menginternalisir ajaran agamanya. Dengan demikian, fundamentalisme juga bisa disebabkan oleh struktur sosial, ekonomi dan situasi politik yang dihadapi dan melingkupinya. ${ }^{10}$

Secara umum, karakteristik gerakan fundamentalisme Islam adalah sebagai berikut: pertama, adanya sikap dan keprihatinan yang mendalam terhadap degenerasi sosial-moral umat Islam. Kedua, memberi himbuan kepada umat Islam agar kembali mendasarkan pemahaman dan praktik keagamaannya kepada sumber-sumber keagamaan otoritatif, terutama al-Qur'ān dan Sunnah, sehingga menghilangkan praktik-praktik takhayul, bidah, khurafät dalam konteks tradisi keberagamaan. Ketiga, memberikan himbauan kepada umat Islam agar membuang jauh-jauh teologi fatalisme (jabariyah) demi mencapai kemajuan. Keempat, menghimbau umat Islam agar melaksanakan pembaruan lewat jihad. Dalam konteks terakhir ini menurut hemat penulis, sepertinya mereka kurang mengerti arus perubahan modernitas sebagai sebuah fakta kemajuan. Sebagain hal

\footnotetext{
${ }^{9}$ Hendropriyono, Terorisme, 165.

${ }_{10}$ Umi Sumbulah, Konfigurasi Fundamentalisme Islam (Malang: UIN-Malang Press, 2009), 21.
} 
dalam modernitas memang tidak patut diikuti, tetapi menjadi kontraproduktif ketika menegasikan segala bentuk modernitas yang bersifat positif, seperti ilmu pengetahuan dan teknologi.

Sebagaimana dipahami bahwa fundamentalisme merupakan bagian dari budaya modern. Ia lahir dari rahim ketidakadilan sistem dan ideologi sosial-politik modern. Fundamentalisme mewakili kekecewaan yang merata, keterasingan, kecemasan, dan kemarahan yang kerap diacuhkan pemerintah. Bahkan dalam bentuknya yang lebih ekstrem, tidak jarang gerakan fundamentalisme terjerumus kepada tindakan-tindakan kekerasan, dan ini menjadi perhatian penuh bagi media Barat beberapa dekade belakangan. Misi suci agama yang begitu luhur dan mulia dicemari dan bahkan diabaikan. Mengapa keluhuran dan kesucian agama nampak seperti hilang dalam diri kaum fundamentalis? Ajarana-ajaran agama harus disajikan sedemikian rupa, sehingga makna kebenaran agama mengejawantahkan dalam kebaikan, kedamaian, dan kemuliaan kehidupan masyarakat. ${ }^{11}$

Secara normatif, teks-teks agama bersifat ambivalen. Ia bisa menebar perdamaian karena pesan-pesan suci perdamaiannya. Namun, ia juga bisa rentan memicu konflik dan kekerasan karena di antara pesan-pesan tekstualitasnya ada yang mengandung kekerasan. Dalam konteks Islam, beberapa teks yang memicu dan melahirkan perilaku kekerasan oleh kelompok gerakan radikal dapat dilihat misalnya pada teks tentang jihad, yang kemudian disistematisir sebagai "ideologi perang" sehingga sarat kekerasan.

Al-Qur'ān misalnya, di satu sisi berbicara tentang perdamaian (termasuk rekonsiliasi) dan, di sisi lain, membahas pula tentang konflik dan kekerasan 'yang dibenarkan'. Fenomena yang tampak kontradiktif ini erat dengan keberadaan apa yang disebut dalam Q.S. al-Nisā' [3]: 7 sebagai ayat-ayat muḅkamät dan mutashäbihät. Para sarjana Muslim telah memberikan definisi yang begitu beragam terhadap dua istilah ini. Menurut Sahiron Syamsuddin, ayat-ayat yang bermakna 'langsung' (direct meaning) sesuai dengan ide dan pesan moral merupakan ayat-ayat mubkamät, sedangkan ayat-ayat yang tampaknya bertentangan dengan ide moral termasuk ayat-ayat mutashäbihät. Berdasarkan atas hal ini, ayat-ayat tentang perdamaian dan rekonsiliasi, dengan demikian, termasuk ayat-ayat mubkamāt, sedangkan ayat-ayat tentang 'kisah-kisah pengazaban' (punishment

${ }_{11}$ Mudhofir Abdullah dan Syamsul Bakri, Memburu Setan Dunia: Ikhtiyar Meluruskan Persepsi Barat dan Islam tentang Terorisme (Yogyakarta: Suluh Press, 2005), 147. 
stories) dan perang 'yang dibolehkan' (jihad) merupakan ayat-ayat mutashäbihāt. ${ }^{12}$

Banyak kaum Muslim radikal atau bahkan teroris yang menyalahpahami ayat-ayat al-Qur'ān tentang perang. Kesalahpahaman mereka pertama terletak pada pemosisian ayat-ayat ini dalam level yang sama dengan ayat-ayat perdamaian, sehingga ayat-ayat tentang perdamaian harus ditempatkan sebagai naungan dari ayat-ayat tentang perang. Dengan demikian, ayat-ayat tentang perang ini tidak dibaca secara literal dan dengan tidak mengabaikan konteks tekstual dan historisnya. ${ }^{13}$

Purnomo $^{14}$ memaparkan bahwa beberapa kejadian yang bisa dianggap sebagai aksi kekerasan yang dilancarkan oleh beberapa umat Islam, terutama di Timur Tengah seperti Iran, Sudan, Lebanon, Somalia, Afganistan, Libya dan beberapa tempat lainnya telah menguatkan dugaan terjadinya kekerasan atas nama agama yang dilekatkan kepada gerakan fundamentalisme Islam. Sebenarnya, realitas Islam di Timur Tengah dari Mesir hingga Pakistan mempunyai banyak wajah dan bentuk, seperti Republik Islam, organisasi oposisi ilegal, dan gerakan-gerakan Islam yang mengajak terjun ke dunia aktivitas sosial dan politik. Banyak pengamat yang mengidentifikasi gerakan-gerakan di atas sebagai anti-modernitas dan anti-Barat. Sebagian lainnya menyebut mereka sebagai reaksi intelektual, kultural, dan dominasi politik atas negara-negara Barat. Sementara itu, Montogomery Watt menyebut mereka tidak lebih dari keinginan para ulama untuk memperkuat kekuasaan dan prestise sosial mereka. ${ }^{15}$

Kaum fundamentalis pada umumnya tidak memberikan ruang bagi pertimbangan nalar dan nurani pada saat melihat dua hal yang bertentangan atau menyimpang dari apa yang diyakini sebagai yang mendasar dari ajaran agama. Mereka tidak memedulikan bagaimana hal yang mendasar itu dirumuskan dan seberapa jauh keterlibatan manusia, dengan kepentingan-kepentingan pribadi atau kelompoknya dan keterbatasan pengetahuan dalam merumuskannya. Mereka menganggap suci poin-poin ajaran dasar yang sebenarnya merupakan

\footnotetext{
12 Sahiron Syamsuddin (ed.), Pesan Damai di Balik Seruan Jihad (Yogyakarta: Bina Mulia Press, 2012), 87.

${ }^{13}$ Ibid., 44.

14 Agus Purnomo, Ideologi Kekerasan: Argumentasi Teologis-Sosial Radikalisme Islam (Yogyakarta: Pustaka Pelajar, 2009), 24.

15 Ainur Rofiq Al Amin, Membongkar Proyek Kbilafab ala Hizbut Tabrir di Indonesia (Yogyakarta: LKiS, 2012), 1.
} 
produk pemahaman manusia atas pesan Tuhan yang disampaikan melalui kitab suci. ${ }^{16}$

Meski umumnya gerakan fundamentalisme mencari inspirasi pada masa lalu sebelum modernitas, tetapi mereka tidak primitif kembali ke abad pertengahan. Semua, secara instrinsik, merupakan gerakan modern dan tidak akan muncul pada zaman lain selain zaman sekarang. Semuanya inovatif dan sering radikal dalam reinterpretasi mereka atas agama. Dengan demikian, fundamentalisme merupakan bagian penting dari panorama modern. Di mana pun modernitas berakar, gerakan fundamentalis kemungkinan akan bangkit bersama dalam reaksi sadar terhadapnya. Fundamentalis akan sering mengungkapkan ketakpuasan mereka atas perkembangan modern dengan selalu menekankan ragam unsur dalam tradisi mereka yang bertentangan dengan itu. ${ }^{17}$

Menurut Bassam Tibi, karakter fundamentalisme agama itu di antaranya: pertama, mempunyai agenda politisasi agama yang agresif dan dilakukan demi mencapai tujuan-tujuannya. Kedua, fundamentalisme, baik Islam ataupun yang lain, merupakan bentuk superfisial dari terorisme atau ekstremisme. ${ }^{18}$

Selama ini sikap Barat terhadap seluruh negara Islam didasarkan atas asumsi akan irasionalitas dan sifat senang bermusuhan dalam diri kaum Muslim. Muncul suatu kecenderungan untuk melihat masyarakat Islam sebagai masyarakat yang opresif, agresif, brutal, fanatis, dan bercirikan keterbelakangan abad pertengahan. Sikap negatif Barat ini cenderung melihat ideologi dan tindakan fundamentalisme Islam yang antagonistik dan suka bertempur di berbagai belahan dunia Islam, dan gambaran inilah yang digunakan mereka untuk mempertegas dan memperkuat pandangan mereka tentang ideologi dan tindakan antagonis kaum Muslim. ${ }^{19}$

\section{Wacana Pemikiran Politik dalam Islam}

Wacana tentang pemikiran politik dalam Islam yang berkaitan dengan sistem khiläfah dapat ditelesuri semenjak Nabi Muhammad

\footnotetext{
${ }_{16}$ Machasin, Islam Dinamis Islam Harmonis: Lokalitas, Pluralisme, Terorisme (Yogyakarta: LKiS, 2011), 291.

17 Armstrong, Sejarah Islam, 233.

18 Bassam Tibi, Ancaman Fundamentalisme: Rajutan Islam Politik dan Kekacauan Dunia Baru, terj. Imron Rosyidi (Yogyakarta: Tiara Wacana, 2000), x.

19 Abdullah Ahmed An-Na'im, Islam Politik dalam Kancab Politik Nasional dan Relasi Internasional, terj. Hasibul Khoir (Yogyakarta: Ar-Ruzz, 2003), 193.
} 
wafat. Dalam konteks ini dapat dikatakan bahwa wacana politik dalam Islam merupakan fenomena paling awal dibandingkan dengan pemikiran dalam bidang teologi dan hukum. Hal ini dapat dipahami bahwa seorang pemimpin sebagai pengganti Nabi merupakan sesuatu yang terlebih dahulu dibutuhkan untuk meneruskan misi yang sebelumnya telah dibangun oleh Nabi. Oleh karena itu tidak bisa dipungkiri bahwa masyarakat Madinah pada saat itu lebih disibukkan dengan masalah suksesi kepemimpinan pengganti Nabi.

Setelah wafatnya Nabi, para pemuka Muslim harus meneruskan bentuk apa yang diambil oleh ummah. ${ }^{20}$ Sebagian mungkin tidak yakin bahwa harus ada sebuah "negara"; bentuk pemerintahan yang belum pernah ada sebelumnya di Arab. Beberapa tampaknya berpikir bahwa setiap kelompok suku harus memilih sendiri imam atau pemimpinnya. Tetapi sahabat Nabi, Abū Bakr dan 'Umar b. al-Khattāāb, menyatakan bahwa ummah harus menjadi komunitas yang bersatu dan harus memiliki penguasa tunggal, sebagaimana dulu di bawah Nabi. Sebagian berkeyakinan bahwa Muhammad tentunya menghendaki digantikan oleh 'Alī b. Abī Tạalib, kerabat lelaki terdekatnya. Di Arab, di mana ikatan darah dianggap suci, orang meyakini bahwa sifat-sifat khusus seorang pemimpin diwarisi melalui garis keturunan. Meski demikian, karena beberapa pertimbangan, akhirnya Abū Bakr yang terpilih sebagai khalifah pertama Nabi oleh mayoritas suara. ${ }^{21}$

Dalam konteks sejarah, pemikiran politik dalam Islam memiliki banyak variasi, namun demikian ada prinsip-prinsip umum yang bermunculan. Misalkan, syarat yang sekurang-kurangnya bagi pemerintahan Islam bukanlah melalui watak kepala negara, tetapi sebuah sistem pemerintahan yang sesuai dengan shari' ${ }^{-} a h$. Pengakuan pihak penguasa bahwa shari'‘ ah itu hukum resmi dalam negara telah dengan tegas menjamin kesatuan masyarakat dalam pola-pola yang ditentukan oleh sharī'ah. Hukum Islam misalnya, bukan hanya sekadar komitmen keagamaan maupun watak moral yang harus diikuti oleh

\footnotetext{
20 Terkait kata kunci ummah dalam al-Qur'ān, lihat ulasan pemikiran Jamāl al-Bannā yang ditulis Mukhammad Zamzami, "Islam sebagai Agama dan Umat: Analisa Pemikiran Kenegaraan Jamâl al-Bannâ", Teosofi: Jurnal Tasawuf dan Pemikiran Islam, Vol. 1, No. 1 (2011), 93-112. Bandingkan dengan Mukhammad Zamzami, "Pemikiran Jamal al-Banna tentang Relasi Agama dan Negara" (Tesis--Universitas Islam Negeri Sunan Ampel Surabaya, 2008).

${ }^{21}$ Armstrong, Sejarah Islam, 74.
} 
pihak penguasa, tetapi hal ini merupakan sebuah kriteria bagi legitimasi negara Islam. ${ }^{22}$

Sebagaimana penjelasan di atas, agama memiliki pandangan dunia sekaligus gagasan dalam membimbing kehidupan pribadi dan kehidupan bersama. Pada masa kepemimpinan al-Khulafä' alRāshidūn maupun pada masa dinasti Bani Umayah serta dinasti Bani 'Abbāsīyah, dasar ideologi masyarakat ataupun negara adalah Islam. Legitimasi dan orititas penguasa, hukum yang diakui secara resmi oleh negara, begitu pun lembaga-lembaga peradilan, pendidikan dan sosial, adalah berakar kepada Islam. Sekalipun realita sejarah dan politik dari kehidupan kbiläfah sering terjadi keganjilan-keganjilan jika dilihat dari ideal Islam, akan tetapi prinsip yang primer dari identitas politik maupun hubungan sosial tetap memiliki kaitan dengan shari ${ }^{-6} a{ }^{23}$

Tiga kerajaan besar Islam diciptakan pada akhir abad kelima belas dan awal abad keenam belas, yaitu Kekaisaran Safawi di Iran, Kekaisaran Moghul di India, dan Kekaisaran 'Uthmānī di Anatolia, Suriah, Afrika Utara, dan Arab. Pemerintahan mengesankan lainnya juga muncul. Sebuah negara Muslim besar dibentuk di Uzbekistan atau negara lain dengan kecenderungan Shî'î didirikan di Maroko. Periode ini bisa dikatakan sebagai sebuah masa kejayaan politik Islam. Namun, ketiga kerajaan besar itu tampaknya berpaling dari tradisi egaliter Islam dan mendirikan monarki absolut. Terlepas dari itu, semua kerajaan baru ini memiliki orientasi Islam yang kuat, didorong oleh para penguasanya sendiri. Di Iran Safawi, Shī'ah mejadi agama negara, falsafah dan tasawuf berpengaruh dominan pada kebijakan Moghul, sementara Kekaisaran 'Uthmānì dijalankan sepenuhnya menurut aturan shari ${ }^{-} a h .{ }^{24}$

Pada masa-masa yang lebih belakangan, setelah tiga bentuk sistem politik dan kekuasan Islam di atas runtuh, banyak yang mendesak untuk kembali kepada prinsip dan nilai-nilai Islam yang dianggap telah membuat negara-negara Muslim begitu kuat sepanjang sejarah. Mereka bersikukuh bahwa umat Islam harus meraih kembali warisan, sejarah, budaya, dan nilai-nilai Arab-Islamnya. Pencarian akan jati diri yang lebih historis dan autentik memicu bangkitnya agama dalam

\footnotetext{
${ }^{22}$ John. L. Esposito, Islam dan Politik, terj. H. M. Joesoef Sou'yb (Jakarta: Bulan Bintang, 1990), 41.

${ }^{23}$ Ibid., 42.

24 Armstrong, Sejarah Islam, 175.
} 
politik dan masyarakat di seluruh dunia Muslim; sebuah kekuatan yang terus mempengaruhi politik Muslim dewasa ini. ${ }^{25}$

Di era modern, perjuangan melawan dominasi kolonial dan konflik antara beberapa elit muslim, masing-masing membawa dirinya sebagai sebuah varian padangan kesejarahan kultur politik Muslim, yang telah menyokong pembentukan masyarakat Muslim modern. Pada sebagian terbesar negara Muslim, hasil dari perjuangan tersebut adalah struktur masyarakat bersendi tiga. Ketiga sendi tersebut meliputi rezim negara sekuler, sebuah badan yang secara bersamaan dapat dibedakan dari asosiasi keagamaan non-politik Muslim dan gerakan perlawanan yang menghendaki rekonstruksi sebuah negara Muslim dan masyarakat Muslim yang integrated. ${ }^{26}$

Sementara itu, sejumlah aspirasi gerakan-gerakan Muslim membangkitkan cita-ideal Islam terhadap sistem kekhalifahan, tetapi dalam banyak hal gerakan ini merupakan sebuah adaptasi baru konsep-konsep Islam terhadap kondisi modern. Sebenarnya, gerakangerakan Islam baru tersebut membawa sedikit kandungan teks suci, hukum, teologi, atau mistisisme tradisional. Meskipun gerakangerakan tersebut berasal dari varian kecenderungan reformasi terdahulu, namun gerakan tersebut dipimpin oleh pada dai seperti Ḥasan al-Bannā yang pemimpin al-Ikebwàn al-Muslimūn, Abu al-A 'lā alMawdūdī, dan Jama'at-Islami, yang mana mereka sendiri bukan ulama atau sufi. ${ }^{27}$

Secara garis besar, mayoritas pemerintahan bangsa-bangsa Muslim telah melakukan tipe pembaruan sejak pertengahan abad XIX. Pertama, mengganti sharī'ah dengan hukum sekuler dalam masalahmasalah perdagangan, sipil, konstitusi, dan pidana. Di sebagian dunia Muslim, hanya hukum keluarga dan waris yang diwujudkan dalam bentuk sharî́ah. Kedua, pembaruan dilakukan dengan tetap mengakui psinsip-psinsip dan aturan sharī'ah seperti diterapkan dalam hukum keluarga dan waris bagi umat Islam. ${ }^{28}$

\footnotetext{
25 John. L. Esposito, Masa Depan Islam: Antara Tantangan Kemajemukan dan Benturan dengan Barat, terj. Eva Y. Nukman dan Edi Wahyu (Bandung: Mizan, 2010), 103.

${ }^{26}$ Ira. M. Lapidus, Sejarah Sosial Ummat Islam, terj. Ghufron A. Mas’adi (Jakarta: Raja Grafindo Persada, 1999), 519.

27 Ibid., 527.

28 Abdullah Ahmed An-Na'im, Dekonstruksi Syariab: Wacana Kebebasan Sipil, Hak Asasi Manusia dan Hubungan Internasional dalam Islam, terj. Ahmad Suaedy dan Amirudin ar-Rany (Yogyakarta: LKiS, 2011), 75.
} 
Ambiguitas sekularisasi dan Islamisasi serta benturan antara konsep sekuler dan Islam mengenai tatanan moral dan politik melahirkan kontinuitas struktur institusional masyarakat Islam. Misalnya, pola hubungan antara institusi negara dan institusi agama di Turki, Negeri Arab, Afrika Utara, Pakistan, Indonesia, Malaysia, Senegal, dan di beberapa negeri lainnya merupakan variasi yang sah atas pola sejarah masyarakat Muslim di sejumlah wilayah tersebut. Sementara elit politik berusaha mempertahankan sinkretisme antara bentuk-bentuk kultur Islam dan kultur kosmopolitan, kebangkitan Islam justru menumbuhkan identitas keagamaan personal dan tanggung jawab komunal. ${ }^{29}$

Bagi seorang Muslim, watak Islam dalam sejarah Muslim dan kehidupan politik tidak dirusak oleh perbedaan sejarah. Watak generasi Muslim belakangan banyak mewarisi pemahaman yang romantik dan idealistik dari sejarah politik Islam dan begitupun berkaitan dengan hukum Islam mengikuti pola-pola yang dikembangkan oleh para ulama terdahulu. Meski banyak pengaburan dan ketimpangan dalam realitas sejarah politik Islam, tetapi ide tentang relasi agama dan negara yang telah dilaksanakan oleh generasi masa lalu telah banyak mengilhami generasi-generasi berikutnya. Gerakan membangkitkan semangat agama pada masa lalu telah banyak memberikan inspirasi kepada aktivis-aktivis politik Islam dewasa ini yang berkeinginan mengejar keterbelakangan dan merealisir perpaduan politik dan agama sepanjang sejarah Islam. Lebih lanjut, Armstrong mengungkapkan:

Politik bukanlah masalah sekunder bagi umat Islam. Kita telah melihat bahwa politik merupakan panggung pencarian agama bagi kaum Muslim. Penyelamatan bukan berarti penebusan dari dosa, melainkan menciptakan masyarakat yang adil di mana individu bisa dengan lebih mudah melakukan penyerahan diri eksistensi seluruh keberadaan dirinya yang akan mendatangkan kepuasaan. Oleh karena itu, pemerintahan adalah masalah yang sangat penting, dan sepanjang abad kedua puluh muncul satu demi satu upaya untuk menciptakan sebuah negara yang benar-benar Islam. Hal ini selalu sulit, ini adalah aspirasi yang memerlukan ijtihad, perjuangan yang tidak dapat menemukan hasil yang sederhana. ${ }^{30}$

Umat Islam pada umumnya mengembangkan suatu jenis religiositas secara langsung dalam menghadapi kondisi politik dan

\footnotetext{
${ }^{29}$ Lapidus, Sejarah Sosial, 567.

30 Armstrong, Sejarah Islam, 224.
} 
realitas sosial terkini yang tidak jarang begitu menggusarkan. Jika institusi negara, misalnya, tidak sejalan dengan nilai-nilai ideal alQur'ān, jika pemimpin politik kejam dan eksploitatif, atau jika komunitas Muslim dihinakan oleh musuh-musuh yang jelas tidak religius, orang Islam biasanya dapat merasakan bahwa iman mereka dalam tujuan tertinggi kehidupan sedang terancam. Dengan demikian, politik adalah arena tempat kaum Muslim mengalami Tuhan dan yang memampukan yang Ilahi untuk berfungsi secara efektif di dunia. Oleh karena itu, cobaan dan bencana dalam sejarah umat Islam, pembantaian politik, perang sipil, invasi, serta jatuh-bangunnya dinasti yang berkuasa tidak pernah terpisah dari pencarian batin agama, tetapi merupakan esensi visi Islam. ${ }^{31}$

Menurut 'Alī 'Abd al-Rāziq, sebagaimana dikutip oleh An-Na'im ${ }^{32}$, menyatakan bahwa tidak ada otoritas Islam untuk konsep khiläfah dalam pengertian historis. Islam sebenarnya tidak memiliki komponen sistem politik yang sistematis. Nabi, misalnya, adalah seorang pemimpin agama dan spiritual, bukan pemimpin politik. Meski kenyataannya pada saat itu Muhammad bertindak sebagai pemangku otoritas hukum sekaligus pemimpin politik, tetapi hal ini terjadi atas keterdesakan-keterdesakan Nabi dalam merumuskan kebijakan yang luas bagi keberlangsungan hidup umat Islam secara keseluruhan. Sehingga, jika dilihat dari tolok ukur modern, banyak rumusanrumusan sharī'ah yang tidak memadai dan mengandung kelemahan yang serius dalam arti pembentukan sebuah sistem negara Islam.

Banyak pengamat yang berpendapat bahwa formalisasi ajaranajaran Islam akan mengubahnya dari agama menjadi ideologi yang batas-batasannya akan ditentukan berdasarkan kepentingan politik. Islam yang semula bersifat terbuka dan luas, hidup layaknya organisme yang komunikatif dan interaktif dengan situasi dan kondisi penganutnya, dan akan dibungkus dalam kemasan ideologis dan berubah menjadi monumen yang diagungkan tanpa peduli pada tujuan sejati dan luhur agama itu sendiri. Akhirnya, agama menjadi ghāyah (tujuan akhir), bukan lagi jalan sebagaimana semula yang diwahyukan. Keridhaan Allah yang semula merupakan ghäyah pun semakin jauh. ${ }^{33}$

\footnotetext{
${ }^{31}$ Ibid., 12.

32 An-Na'im, Dekonstruksi Syariah, 72.

33 A. Mustafa Bisri, "Belajar Tanpa Akhir", dalam Abdurrahman Wahid (ed.), Ilusi Negara Islam: Ekspansi Gerakan Islam Transnasional di Indonesia (Yogyakarta: The Wahid Insitute, 2009), 234.
} 
Demikianlah, seharusnya cita-cita yang ideal bagi gerakan kebangkitan Islam tidak hanya berakar pada institusi tetapi juga dalam pemaknaan simbolik dan kultural terhadap Islam. Inilah sebuah citacita paling ideal dalam membawa misi keislaman. Karena, hampir semua tragedi-tragedi menyakitkan yang berasal dari perjuangan dan pembelaan atas nama agama adalah diakibatkan dari kesalahan dalam menafsirkan agama itu sendiri. Agama memang memiliki seribu tafsir atau bahkan lebih, tetapi rumusannya tetap berakar pada bentuk transendensi diri dengan secara keseluruhan melibatkan sebuah persamaan tindakan dan kesatuan prinsip yang kokoh bagi semua masyarakat Muslim.

\section{Analisis Kritis Nalar Teologi Politik Fundamentalisme Islam}

Secara konseptual, nalar teologi politik dari kelompok fundamentalisme Islam berupaya menfokuskan diri pada perkembangan tatanan sosial-politik Islam di dalam komunitas Muslim. Mereka menolak, setidaknya pada tataran teoritis, ideologiideologi modern seperti nasionalisme, sekularisme dan komunisme. Mereka juga menolak "Westernisasi". Kelompok fundamentalis ini memperjuangkan reformasi dan perubahan di dalam komunitaskomunitas Muslim, menekankan pada nilai-nilai dan institusi-institusi yang 'Islami' untuk menggantikan apa yang mereka pandang sebagai nilai-nilai dan norma-norma Barat. Mereka tertarik untuk mendirikan negara Islam. Menurut Abdullah Saeed, sebagian kecil dari mereka memilih jalan pendekatan revolusioner terhadap apa yang mereka anggap sebagai pemerintahan negara Muslim, meskipun jalan ini harus dilakukan dengan cara kekerasan. Sementara sebagian kelompok politis yang lain, mereka memilih pendekatan yang gradual melalui jalan pendidikan, dimulai dari tingkat akar rumput. ${ }^{34}$

Al-Qur'ān menegaskan bahwa tugas utama seorang Muslim adalah membangun masyarakat yang adil dan layak, sehingga ketika umat Islam melihat ummah dieksploitasi atau bahkan diteror oleh kekuasaan asing dan diperintah oleh para penguasa korup, mereka bisa sangat tersinggung secara religius. Islam secara tradisional adalah agama kesuksesan. Pada masa lalu, kaum Muslim selalu mampu menghadapi bencana secara kreatif dan menggunakannya untuk naik ke ketinggian spiritual dan politik baru. Al-Qur'ān meyakinkan mereka bahwa jika

34 Abdullah Saeed, Pemikiran Islam: Sebuah Pengantar, terj. Syahiron Syamsuddin dan M. Nur Prabowo (Yogyakarta: Baitul Hikmah Press, 2014), 258. 
masyarakat mereka adil dan egaliter, masyarakat itu akan makmur. Hal ini bukan berarti bahwa Allah mengutak-atik sejarah atas nama mereka, melainkan karena pemerintahan semacam ini sejalan dengan hukum fundamental eksistensi. Tetapi, kaum Muslim hanya mampu melakukan kemajuan kecil melawan sekuler Barat dan sebagian merasakan ini sebagai ancaman seperti halnya bagi kelompok fundamentalis Islam..$^{35}$

Dapat dikatakan, sistem Islam menjamin bahwa negara tidak ditentukan oleh hasrat dan ambisi penguasanya. Ia membebaskan kaum Muslim dari ketidaktetapan dan kejahatan kekuasaan manusia. Dengan prinsip shürā (konsultasi) dalam hukum Islam, khalïfah wajib bermusyawarah dengan rakyatnya, tetapi tidak berarti pemerintahan menurunkan legitimasinya dari rakyat, seperti dalam cita-cita demokrasi. Khalifah dan rakyat tidak bisa menciptakan hukum mereka sendiri, mereka sekadar melaksanakan sharīah. Oleh karena itu, kaum Muslim harus melawan bentuk pemerintahan Barat yang dipaksakan kepada mereka oleh kekuasaan kolonial, sebab pemerintahan itu merupakan bentuk pemberontakan melawan Allah. Sekali manusia merampas kekuasaan, maka akan muncul ancaman kejahatan, penindasan, dan tirani. Ini merupakan teologi pembebasan yang kedengaran aneh bagi seorang sekularis yang teguh, tetapi itulah kodrat sebuah ideologi yang paham-pahamnya tak dapat dimengerti pihak penentangnya. ${ }^{36}$

Secara ideologis, sebenarnya gerakan fundamentalisme Islam mudah dilemahkan oleh perpecahan Islam itu sendiri, sebagaimana sebelumnya bahwa Islam memiliki banyak perbedaan. Kaum Muslim terbagi menjadi beberapa aliran dengan pandangan yang berbedabeda. Tetapi ini bukan dalam bentuk persaingan identitas sosial dan nasional. Ini hanya bentuk pandangan atas penafsiran ajaran Islam sendiri. ${ }^{37}$

Ketakutan kaum fundamentalis akan kehancuran sebenarnya bukanlah khayalan belaka. Kita dapat melihat bahwa beberapa dari pencipta etos modern yang paling formatif memang telah menyerukan penghapusan agama, dan mereka terus melakukan hal itu. Semua gerakan ini dimulai dari apa yang dianggap sebagai serangan dari

${ }^{35}$ Karen Armstrong, Sejarah Tuhan: Kisah 4000 Tabun Pencarian Tuban dalam AgamaAgama Manusia, terj. Yuliani Liputo (Bandung: Mizan, 2011), 467.

36 Armstrong, Berperang Demi Tuhan, 366.

37 Steve Bruce, Fundamentalisme, terj. Herbhayu Noerlambang (Jakarta: Erlangga, 2000), 84. 
sesama pemeluk agama yang liberal atau rezim sekuler, dan serangan lebih lanjut hanya membuat mereka lebih ekstrem. Dalam konteks kemunduran umat Islam dan bagaimana Islam melihat Barat, Armstrong secara khusus mengungkapkan:

Keliru besar membayangkan bahwa Islam menyebabkan umat Islam mundur secara instingtif dari Barat modern. Pada pergantian abad ke-20, setiap intelektual Muslim terkemuka, sebagaimana ideolog Iran Jamāl al-Dīn al-Afghānī, jatuh cinta dengan Barat, dan mengakuinya pada tingkatan yang mendalam, dan ingin agar negara-negara mereka terlihat seperti Inggris dan Prancis. Muhammad Abduh dari Mesir, misalnya, membenci pendudukan Inggris atas negaranya, tetapi merasa nyaman dengan budaya Barat. ${ }^{38}$

Dalam segala bentuknya, fundamentalisme adalah iman yang sangat reduktif. Dalam kecemasan dan ketakutan mereka, kaum fundamentalis sering mendistorsi tradisi yang coba mereka bela. Mereka terlalu fanatik dan menolak apapun yang datang dari musuh. Hal ini merupakan tindakan yang sangat tidak bijaksana dan terlalu egois. Gerakan fundamentalisme Islam yang cenderung anarkis dan radikal bukanlah gerakan pemurnian tetapi justru sebaliknya. Armstrong menambahkan bahwa banyak fundamentalis Muslim mengabaikan pluralisme dalam al-Qur'ān dan kaum ekstremis mengutip ayat-ayat al-Qur'ān yang lebih agresif untuk membenarkan kekerasan. Kaum fundamentalis yakin bahwa mereka berjuang atas nama Tuhan, tetapi sebenarnya religiositas jenis ini mewakili kemunduran dari Tuhan.

Sebenarnya, sikap militansi Muslim abad ke-20 dan awal abad ke21 dikenal berkat adanya sejumlah aktivitas yang mencakup perjuangan kemerdekaan secara lokal di beberapa negara, perjuangan secara internasional seperti Perang Afghan Pertama (sebagai hasil dari pendudukan Uni Soviet atas Afghanistan), dan aktivitas-aktivitas yang anti-Barat yang diselenggarakan oleh para militan ekstrem seperti Osama bin Laden. Pada awal abad ke-21, isu yang dominan dalam perdebatan seputar militansi dan ekstremisme Muslim adalah tentang aktivitas-aktivitas anti-Barat, terutama akibat dari peristiwa 11 September dan berbagai aksi pengeboman yang terjadi baik di negara Muslim sendiri maupun di Barat oleh jaringan kelompok ekstremis militan dunia. Ini semua didorong oleh pandangan terhadap dunia yang

38 Armstrong, Sejarab Tuban, 471. 
diliputi ketidakadilan terhadap umat Muslim sehingga menimbulkan simpati yang mendalam. Didukung pula dengan narasi yang menambah kuatnya rasa simpati ini, dimulai sejak Perang Salib hingga menginjak pada dominasi kolonialisme oleh Barat terhadap umat Muslim. ${ }^{39}$

Berikut ini akan ditulis petikan dari fatwa yang dikeluarkan oleh Osama bin Laden dan beberapa pendukungnya yang menghimbau umat Muslim untuk membunuh orang-orang Amerika dan sekutusekutunya:

Sesuai dengan seruan Allah, kami mengeluarkan fatwa berikut ini untuk semua umat Muslim. Membunuh orang-orang Amerika beserta sekutu-sekutunya, baik sipil maupun militer, merupakan kewajiban bagi setiap Muslim yang bisa melakukannya di negara manapun yang memungkinkan melakukannya, agar supaya Masjid al-Aqsha dan Masjid al-Haram terbebas dari cengkeraman mereka, dan agar tentara mereka keluar dari tanah Muslim, kalah dan tidak bisa mengancam umat Muslim. Ini sesuai dengan firman Allah: "Dan perangilah orang-orang musyrik itu semuanya seperti mereka memerangimu semuanya," dan "perangilah mereka itu hingga tidak ada lagi fitnah, dan sehingga ketaatan itu hanya semata-mata untuk Allah". Ini adalah tambahan firman Allah: "Mengapa kamu tidak mau berperang di jalan Allah dan membela orang-orang yang lemah baik laki-laki, wanita-wanita maupun anak-anak yang semuanya berdoa: "Ya Tuhan kami, keluarkanlah kami dari negeri ini yang zalim penduduknya dan berilah kami perlindungan dari sisi Engkau, dan berilah kami penolong dari sisi Engkau!" Kami dengan pertolongan Allah, menyerukan kepada setiap Muslim yang beriman kepada Allah dan yang mengharapkan pahala karena menjalankan perintah-Nya untuk membunuh orang-orang Amerika dan merampas harta mereka dimanapun dan kapanpun mereka berada. Kami juga menyerukan kepada ulama Muslim, para pemimpin, kaum muda, dan para tentara untuk melancarkan serangan terhadap pasukan-pasukan setan AS dan para pendukung iblis yang bersekutu dengan mereka, dan untuk menyingkirkan siapapun yang berada di balik mereka sehingga mereka bisa mengambil pelajaran. ${ }^{40}$

Fatwa ini sebenarnya telah mendapat kritik oleh banyak kalangan Muslim di seluruh dunia, dan tentu saja, sejumlah fatwa tandingan pun telah dikeluarkan. Bentuk pemahaman terhadap perjuangan Islam

\footnotetext{
${ }^{39}$ Ibid., 472.

${ }^{40}$ Saeed, Pemikiran Islam, 268.
} 
sebagaimana dikumandangkan Bin Laden di atas telah menimbulkan semacam guncangan dahsyat secara global. Ini merupakan guncangan yang begitu mendalam bagi seluruh umat Islam di dunia, betapa pemahaman Laden ini begitu sempit dan sangat dekaden.

Sebagaimana tampak jelas dalam keganasan serangan pada 11 September, yang telah begitu membawa perang fundamentalis melawan modernitas memasuki fase baru. Sebagian besar umat Islam merasa ngeri dengan serangan September ini dan menunjukkan bahwa kekejaman seperti itu bertentangan dengan prinsip-psinsip paling suci Islam. Al-Qur'ān mengutuk semua perang agresif dan mengajarkan bahwa satu-satunya perang yang diperbolehkan adalah perang membela diri. Tapi, Osama bin Laden dan murid-muridnya mengklaim bahwa umat Islam sedang di bawah serangan. Dia menunjuk kehadiran tentara Amerika di Tanah Suci Arabia; hingga pengeboman terus-menerus atas Irak oleh pesawat tempur Amerika dan Inggris, hingga penjatuhan sanksi yang dipimpin oleh Amerika terhadap Irak, yang mengakibatkan ribuan warga sipil dan anak-anak meninggal dunia, hingga kematian ratusan warga Palestina di tangan Israel, sekutu utama Amerika di Timur Tengah, serta dukungan yang diberikan Amerika kepada pemerintah yang dianggap Bin Laden sebagai korup dan menindas, seperti keluarga Arab Saudi.

Menurut Armstrong, walau bagaimanapun cara kita melihat kebijakan luar negeri Amerika, semua itu tak dapat membenarkan serangan mematikan seperti itu, yang tidak memiliki pembenaran baik dalam al-Qur'ān maupun sharí'ah. Hukum Islam melarang seorang Muslim untuk menyatakan perang terhadap negara di mana kaum Muslim diizinkan beribadah secara bebas, dan sangat melarang pembunuhan warga sipil tak berdosa. ${ }^{41}$

Secara spesifik, gerakan fundamenalis di atas memiliki tiga misi sebagai bentuk perjuangan, yakni mendirikan pemerintahan Tuhan di atas muka bumi, mati syahid demi menjalankan perintah Tuhan, dan memurnikan umat Islam dari kemaksiatan. Ini sebenarnya merupaan sasaran utopis dari gerakan fundamentalis al-Qaeda yang dipimpin oleh Bin Laden waktu itu. Tetapi, perlu dipahami bahwa gerakan ini harus dilihat sebagai bentuk fundamentalisme yang paling ekstrem dan militan yang terjebak dalam ranah terorisme, bukan menggambarkan secara keseluruhan bentuk perjuangan dari kelompok fundamentalisme di seluruh dunia. Sebagaimana Armstrong

${ }^{41}$ Armstrong, Berperang Demi Tuban, 259. 
sendiri mengungkapkan bahwa para ekstremis ini sama sekali berbeda dari para fundamentalis normal yang menjalani kehidupan ortodoks secara ketat dan memandang kelompok lama sebagai simbol jähilīyah yang selamanya dan senantiasa merupakan musuh sejati iman. ${ }^{42}$

Banyak kalangan di Barat umumnya bingung memahami Islam. Pemimpin kaum Muslim mengatakan bahwa Islam adalah agama damai dan adil, namun Osama bin Laden dan fundamentalis militan lainnya secara global membantai non-Muslim. Presiden George W. Bush menyebut Islam sebagai agama damai sementara penginjil Franklin Graham memandang Islam sebagai agama setan. Samuel Hantington, penulis The Clash of Civilizations mengatakan: "Islam berlumur darah di luar, dan di dalam". Tapi, sebagaimana dikemukakan oleh Presiden Barack Obama: "Islam telah menunjukan lewat kata-kata dan perbuatan tentang peluang toleransi beragama dan kesetaraan ras, kemitraan Amerika dan Islam harus didasarkan pada Islam yang sesungguhnya, bukan pada apa yang bukan Islam." ${ }^{93}$

Pola pikir khas kaum fundamentalis adalah keyakinan bahwa hanya ada satu cara menafsirkan kenyataan. Ini sebenarnya yang menjadi titik paling inti dari semua permasalahan yang menjangkiti gerakan fundamentalisme Islam. Mereka tampak tidak kenal kompromi dalam misi perjuangannya, dan semata-mata melihat bahwa perjuangan itu adalah berada di jalan Allah, sehingga apapun yang dilihat sebagai bentuk ancaman dan kemaksiatan harus segera ditumpas tanpa mempertimbangkan nilai-nilai kemanusiaan.

Masa depan Islam yang lebih baik terletak pada bagaimana kemajemukan dapat hidup secara damai dan umat Islam mampu bersikap secara bijak terhadap Barat. Masa depan Islam juga tidak terbatas hanya tergantung pada efektivitas segelintir pembaru Muslim, tetapi Barat juga memainkan peranan besar. Apabila semua kebijakan Barat yang berpandangan picik telah membantu menciptakan kebuntuan seperti sekarang ini, kebijakan-kebijakan itu, jika tidak diperbaiki, akan terus berdampak negatif terhadap wilayah tersebut, akan melemahkan alasan reformasi, dan terjatuh ke tangan fundamentalisme yang ekstremis. Gerakan fundamentalisme Islam pada gilirannya dianggap mengganggu proyek kebangkitan dalam Islam yang lebih progresif dan kontekstual.

42 Lawrence Wright, Sejarah Teror: Jalan Panjang Menuju 11/9, terj. Hendra (Yogyakarta: Kanisius, 2011), 377.

${ }^{43}$ Esposito, Masa Depan Islam, 31. 
Islam adalah agama damai dan hanya dengan prinsip perdamaian yang selamanya dapat menyatukan umat manusia. Salah satu tugas utama generasi kita adalah membangun komunitas global, tempat orang-orang dari semua keyakinan bisa hidup bersama secara harmonis dan saling menghormati. Antara Barat dan Islam harus lebih saling memahami dan menumbuhkan sikap kerjasama secara global, jika hal-hal yang paling mendasar ini tidak segera terlaksana, maka selamanya dunia ini akan terbelah menjadi dua kubu yang saling bertentangan.

\section{Penutup}

Secara politis, fundamentalisme sejauh ini telah berhasil mengembalikan agama dari tempat peripheral ke main stage, sehingga agama sekali lagi memainkan peranan utama dalam urusan-urusan penting. Tetapi, Armstrong menyimpulkan bahwa fundamentalisme Islam bukan sekadar sebuah cara untuk "menggunakan" agama untuk tujuan politik. Pada dasarnya, selain sebagai upaya untuk membuat nilai-nilai spiritual berlaku di dunia modern, ini adalah sebentuk pemberontakan terhadap pengucilan yang sacred dari kehidupan profane. Namun disayangkan bahwa keputusasaan dan ketakutan yang menggerakkan fundamentalis juga cenderung mendistorsi tradisi keagamaan yang mengajarkan toleransi dan rekonsiliasi. Armstrong menambahkan bahwa tidak benar membayangkan di dalam Islam terdapat aliran militan fanatik yang mendorong Muslim untuk melakukan penolakan gila-gilaan dan penuh kekerasan terhadap modernitas.

Umat Islam tidak bisa menutup mata bahwa prestasi-prestasi zaman modern telah memudahkan mereka dalam menempuh kehidupan yang lebih kreatif dan berkembang. Jika kaum fundamentalis tidak merubah cara berpikir mereka dan tidak bisa bersikap kritis terhadap perubahan-perubahan, maka selamanya identitas mereka akan selalu terbelah, dan dunia ini seakan hanya diisi oleh dua kubu besar yang saling berlawanan, yakni antara kelompok yang membela Allah dan musuh-musuh-Nya. Kita hidup di bumi yang sama dengan masalah-masalah yang sama pula, maka sepantasnya umat manusia bersatu untuk menghadapi tantangan zaman dan berusaha menjadikan dunia ini lebih damai. Tanpa perdamaian umat manusia tidak akan mudah mencapai cita-cita kehidupan yang mereka harapkan. 


\section{Daftar Rujukan}

Armstrong, Karen. Berperang Demi Tuban: Fundamentalisme dalam Islam, Kristen, dan Yahudi, terj. T. Hermaya. Bandung: Mizan, 2013.

-----. Sejarah Islam: Telaah Ringkas-Komprehensif Perkembangan Islam Sepanjang Zaman, terj. Yuliani Liputo. Bandung: Mizan, 2014.

----. Masa Depan Tuhan: Sanggahan terhadap Fundamentalisme dan Ateisme, terj. Yuliani Liputo. Bandung: Mizan, 2011.

-----. Sejarah Tuban: Kisab 4000 Tabun Pencarian Tuban dalam AgamaAgama Manusia, terj. Yuliani Liputo. Bandung: Mizan, 2011.

Abdullah, Mudhofir dan Syamsul Bakri. Memburu Setan Dunia: Ikbtiyar Meluruskan Persepsi Barat dan Islam tentang Terorisme. Yogyakarta: Suluh Press, 2005.

Al Amin, Ainur Rofiq. Membongkar Proyek Khilafah ala Hižbut Tabrir di Indonesia. Yogyakarta: LKiS, 2012.

An-Na'im, Abdullah Ahmed. Islam Politik dalam Kancab Politik Nasional dan Relasi Internasional, terj. Hasibul Khoir. Yogyakarta: Ar-Ruzz, 2003.

-----. Dekonstruksi Syariah: Wacana Kebebasan Sipil, Hak Asasi Manusia dan Hubungan Internasioanal dalam Islam, terj. Ahmad Suaedy dan Amirudin ar-Rany. Yogyakarta: LKiS, 2011.

Bisri, A. Mustafa. "Belajar Tanpa Akhir", dalam Abdurrahman Wahid (ed.). Ilusi Negara Islam: Ekspansi Gerakan Islam Transnasional di Indonesia, Yogyakarta: The Wahid Insitute, 2009.

Bruce, Steve. Fundamentalisme, terj. Herbhayu Noerlambang. Jakarta: Erlangga, 2000.

Esposito, John. L. Islam dan Politik, terj. H. M. Joesoef Sou'yb. Jakarta: Bulan Bintang, 1990.

- Masa Depan Islam: Antara Tantangan Kemajemukan dan Benturan dengan Barat, terj. Eva Y. Nukman dan Edi Wahyu. Bandung: Mizan, 2010.

Hendropriyono, A. M. Terorisme: Fundamentalisme Kristen, Yabudi, dan Islam. Jakarta: Kompas, 2009.

Lapidus, Ira. M. Sejarah Sosial Ummat Islam, terj. Ghufron A. Mas'adi. Jakarta: Raja Grafindo Persada, 1999.

Machasin. Islam Dinamis Islam Harmonis: Lokalitas, Pluralisme, Terorisme. Yogyakarta: LKiS, 2011. 
Purnomo, Agus. Ideologi Kekerasan: Argumentasi Teologis-Sosial Radikalisme Islam. Yogyakarta: Pustaka Pelajar, 2009.

Sumbulah, Umi. Konfigurasi Fundamentalisme Isam. Malang: UIN-Malang Press, 2009.

Saeed, Abdullah. Pemikiran Islam: Sebuah Pengantar, terj. Syahiron Syamsuddin dan M. Nur Prabowo. Yogyakarta: Baitul Hikmah Press, 2014.

Syamsuddin, Sahiron (ed.). Pesan Damai di Balik Seruan Jihad. Yogyakarta: Bina Mulia Press, 2012.

Tibi, Bassam. Ancaman Fundamentalisme: Rajutan Islam Politik dan Kekacauan Dunia Baru, terj. Imron Rosyidi. Yogyakarta: Tiara Wacana, 2000.

Wright, Lawrence. Sejarah Teror: Jalan Panjang Menuju 11/9, terj. Hendra. Yogyakarta: Kanisius, 2011.

Zamzami, Mukhammad. "Islam sebagai Agama dan Umat: Analisa Pemikiran Kenegaraan Jamâl al-Bannâ", Teosofi: Jurnal Tasawuf dan Pemikiran Islam, Vol. 1, No. 1, 2011.

----- "Pemikiran Jamal al-Banna tentang Relasi Agama dan Negara". Tesis--Universitas Islam Negeri Sunan Ampel Surabaya, 2008. 